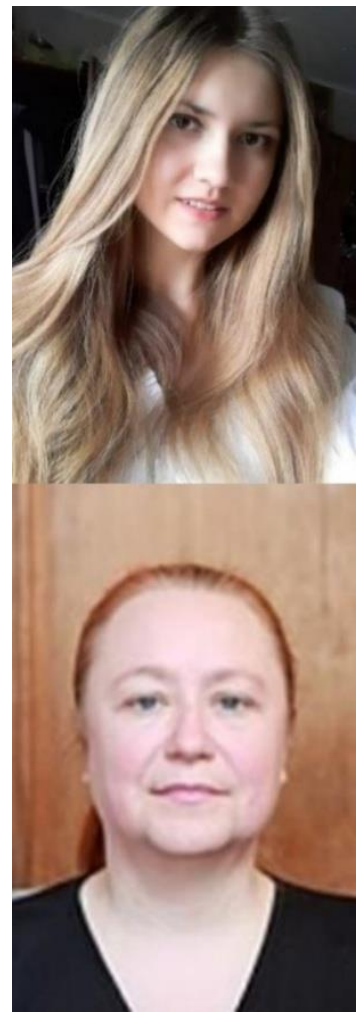

\title{
СОЦИАЛЬНАЯ ЭМЕРДЖЕНТНОСТЬ
}

\author{
О. А. Сахарова, студентка 3-го курса ФБП, \\ e-mail: olga.sakharova.99@mail.ru \\ ФГБОУ ВО «Калининградский государственный \\ технический университет»
}

Н. В. Меднис, канд. филос. наук, доц. кафедры философии и культурологии e-mail: natalymednis@gmail.com

ФГБОУ ВО «Калининградский государственный технический университет»

Статья посвящена анализу восприятия искусства в эпоху цифровых технологий, изменению формата подачи и понимания. Рассматриваются такие понятия, как технологический прогресс и причины социальной эмерджентности, причины, приводящие к тому, что пожилые люди пытаются выглядеть в разы моложе своего реального возраста, государственная политика и средства массовой информации, имеющие влияние на лица пожилого возраста.

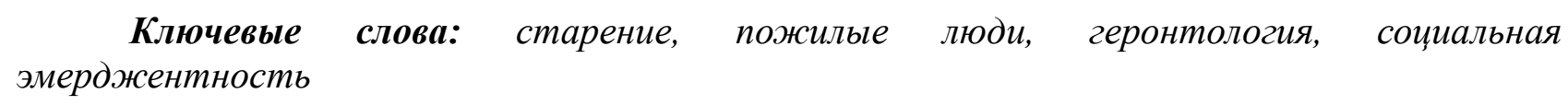

ВВЕДЕНИЕ

Одной из причин распространения эйджистских настроений является технический прогресс. В век цифровизации люди все больше используют Интернет для разных сфер жизни, например, для заработка в сети различными способами от фрилансинга до блогинга, для обращения в государственные учреждения.

\section{ОБЪЕКТ ИССЛЕДОВАНИЯ}

Объект исследования - социальная адаптация пожилых людей в быстроизменяющемся мире прогрессивных технологий

\section{ЦЕЛЬ И ЗАДАЧИ ИССЛЕДОВАНИЯ}

Целью исследования является выявление процессов эмерджентности в социальных системах «третьего возраста». Задачей исследования является нахождение наиболее эффективных видов деятельности. 


\section{МЕТОДЫ ИССЛЕДОВАНИЯ}

Методами исследования являются: анализ, обобщение, синтез, сравнение.

\section{РЕЗУЛЬТАТЫ ИССЛЕДОВАНИЯ}

В век распространения цифровых технологий представители нового поколения быстро осваивают новые тенденции и воплощают их в жизнь, им проще в этом ориентироваться, чем людям более пожилого возраста. Люди преклонного возраста начинают чувствовать себя словно в изоляции, ведь многие нововведения им непонятны. Чтобы помочь разобраться в новых технологиях, организуются курсы по цифровой компьютерной грамотности населения, где учат пожилых людей азам работы за компьютером.

Вместе с цифровизацией наступает эра СМИ, которые внедряют образ богатых и успешных людей с модельными характеристиками внешности, в то время как у многих людей на фоне этого развиваются комплексы неполноценности. Зачастую подобные, зависящие от общества личности всеми силами стараются соответствовать данным стандартам, делая пластические операции, уколы ботокса, беря на себя кредиты на покупку статусных вещей и т. д. Пожилой слой населения в этом плане не является исключением, ведь им тоже хочется соответствовать новомодным веяниям красоты.

В последнее время появилась такая тенденция, что более зрелые дамы посещают те же самые магазины с одеждой, что и подростки, широкая размерная сетка позволяет это сделать. Это говорит о том, что пожилые дамы стараются все чаще выглядеть молодежно, они стесняются своего возраста и пытаются таким образом нивелировать свою возрастную разницу. Данный аспект полностью противоречит законам природы и этики. На взгляд авторов, дамам солидного возраста необходимо следить за собой, но при этом критично оценивать информацию, чтобы преодолевать влияние маркетологов и СМИ о модельной внешности, необходимости в «уколах красоты» и пластических операциях, модной молодежной одежде и яркой косметике на лице. В каждой возрастной категории существует свой наиболее удачный образ жизни, внешности [3].

В последние десятилетия государство, как правило, стало вкладывать в молодежь гораздо больше средств, выращивая уже с малых лет сильных и конкурентоспособных людей для будущего страны. Но не вся молодежь готова брать на себя ответственность и постоянно развиваться, зачастую она инертна и считает, что государство обязано предоставить каждому индивиду комфорт. Молодой категории населения также необходимо как можно раньше задумываться о будущем и действовать уже сейчас, пополняя копилку знаний и навыков, а не думать, что в будущем все успеется и как-нибудь решится [1].

Государственная политика в РФ недостаточно поддерживает пенсионеров, ведь это люди, которые теперь не приносят экономической выгоды, при этом им приходится платить пенсию. Они чаще болеют, необходимы затраты на их лечение, в некоторых случаях также требуется и уход, для чего задействуются социальные службы, но несмотря на все это, организуется и культурный досуг. Для данной категории граждан создаются различные творческие вечера и встречи с различными интересными людьми в библиотеках, в некоторые музеи возможен бесплатный вход в определенные дни или со скидкой, проводятся встречи ветеранов, а также существуют объединения по интересам. Обычно в эти интересы входят культурная деятельность и здоровье, но бывают и те пожилые люди, которые все еще стараются бороться в конкурсах за призовые места в спортивных состязаниях, но, к сожалению, летальный исход для таких смельчаков - это нередкое явление. Геронтологическая особенность как раз в том и заключается, что в старшем возрасте необходимо исключить спорт в конкурсном варианте, но это не говорит о том, что спорт из жизни нужно исключить совсем. Спорт в посильном варианте необходим, ряд упражнений следует скорректировать исходя из рекомендаций врача. Идеальным видом деятельности для данного круга лиц была бы мозговая, такая как, например, шахматы, шашки, домино и различные другие настольные игры. Это было популярно только в СССР, а в нынешнее время 
встречается все реже. Все эти мероприятия для государства и муниципалитетов обходится в малые средства и поэтому не является обременительными.

Зачастую у людей преклонного возраста небольшой круг общения, в который редко приходят новые личности, так как все новое для таких людей начинает вызывать дискомфортные ощущения. Пожилым людям необходимо находиться в обществе и, желательно, своего возраста. Если они находятся среди молодежи, превосходящей их по возможностям или статусу, происходит подавление личности, пожилой человек начинает перекладывать свои проблемы на молодого, тем самым деградируя.

Немаловажную роль для зрелых людей играет церковь, большинство прихожан там являются именно пожилые. Культурный досуг в церквях можно рассмотреть на примере католических храмов, где организуются концерты для прихожан, а также паломнические группы по святым местам. Несмотря на все это, многие люди предпочитают оставаться дома. Это может быть вызвано как возрастными особенностями организма, так и личным желанием. Телевидение, чтение книг и Интернет становятся постоянными спутниками для времяпровождения, но с течением времени наступает развитие деменции, что быстро приводит к деградации [4].

Часто можно услышать фразы «не живи вчерашним днем» или «не живи прошлым, думай о будущем». Что делать людям, у которых, кроме прошлого и настоящего, ничего не осталось? Данные выражения неверны, потому что наша жизнь независимо от ее длины каждую секунду как раз и формирует то самое прошлое. Если изменить к прошлому свое отношение, то это может привести к неожиданным результатам. В этом случае все прошлые ошибки не будут учтены в настоящем времени, не будут проанализированы соответственно и уроки, которые нужно было извлечь из этих ошибок, не будут получены и осознаны. Без прошлого невозможно существование будущего [5].

Ранее социальная значимость старшего поколения была закреплена материальными благами, ценностями. Считалось, что чем старше человек, тем большего в жизни он добился, а наследство, оставляемое им, значительно превышало достаток младшего поколения. Сейчас же все поменялось и зачастую младшее поколение зарабатывает в разы больше своих родителей, но при этом оба этих поколения могут выполнять одну и ту же работу. Именно пожилые люди, имеющие большие накопления, зачастую становятся жертвами мошеннических действий, а также вступают в различные секты. Это пример того, что потенциал системы значительно превосходит потенциал каждого ее участника и это как раз и имеет название - эффект эмерджентности, который проявляется у возрастных групп в значительно большей степени, чем у младших [2].

К сожалению, на данном этапе на государственном уровне нет устойчивой политики на создание образа успешного пенсионера, плодотворно трудящегося на благо себя и общества уже после выхода на пенсию, развивающегося как личность. Таким образом, формируется социальная система с высоким уровнем эмерджентности. Также необходимо с детства прививать молодому поколению уважение к пожилым людям, как это до сих пор развито на Востоке. Например, в Китае считается, что чем старше человек, тем выше его социальный статус, также большего уважения вызывает к себе тот человек, чьи родители прожили как можно дольше, что значит хороший уход, забота и хорошие условия, созданные потомком своим родителям. В деревнях существуют старцы - пожилые люди, почитаемые всей деревней, мудрецы, к которым жители обращаются за советом, а иной раз к ним приезжают и из городов. На Западе же модель поведения пожилых людей и молодого поколения кардинально отличается. Нередко можно услышать обращение внука к бабушке по имени. Это, так называемые, молодящиеся бабушки, для которых обращенное к ним слово бабушка, вызывает бурный протест. Такое поведение через время формирует у внука отношение к бабушке как к сверстнику, впоследствии он начинает ее воспринимать покровительственно и без внутреннего уважения. В качестве еще одного аргумента, подтверждающего данное мнение, можно сказать то, что к старшему поколению на Западе мало кто прислушивается в плане советов, жизненного опыта, также очень мало психологов 
и психотерапевтов, знающих как правильно вести работу с пожилыми людьми. Данная категория людей, обратившись в социальные службы, также может испытывать на себе неприязнь, насмешки и неуважительное отношение к себе со стороны персонала. Такое отношение вызывает у человека негативный отклик, выражающийся в постоянных стрессах, заниженной самооценке, ощущении ненужности, отчужденности и приводит к депрессиям [2].

\title{
ЗАКЛЮЧЕНИЕ
}

Исходя из вышесказанного можно сделать вывод, что, несмотря на быстро меняющееся общество, моду на омоложение, скрывание своих недостатков и признаков старения для достижения мнимого идеала, люди теряют себя, свою индивидуальность, поэтому необходимо научиться принимать свой новый облик, который приходит с годами.

Досуг, подходящий для пожилых людей мало развит, а социальная значимость с выходом на пенсию, к сожалению, заметно снижается. Большинство пенсионеров чувствуют свое постепенное угасание как в физическом, так и в психологическом планах, для них характерен значительный риск развития депрессивных расстройств. Чтобы это предотвратить или хотя бы замедлить, необходимо организовать больше мест, в посещении которых были бы заинтересованы пожилые люди, также необходимо создать те условия, в которых люди в почтенном возрасте чувствовали бы себя нужными обществу.

\section{СПИСОК ЛИТЕРАТУРЫ}

1. Городова, Т. В. Теоретические основы исследования геронтологического эйджизма / Т. В. Городова, Л. В. Колпина // Современные проблемы науки и образования. - 2016. № 1-1. - С. 1439-1140.

2. Анипкин, М. А. Социальная система и проблема интеграции в социологии / М. А. Анипкин. - Москва: Власть.- 2009. - № 6. - С. 103-105.

3. Блау, П. Различные точки зрения на социальную структуру и их общий знаменатель / П. Блау // Американская социологическая мысль: тексты. - Москва, 1996. - 496 с.

4. Бодрин, А. В. Особенности досуговой деятельности пожилых людей / А. В. Бодрин, Л. А. Таболько // Молодой ученый. - 2016. - № 6 (110). - С. 739-741.

5. Крейк, А. И. Эмерджентные следствия социальной функции субинститута «Образование» / А. И. Крейк // Идеи и Идеалы. - 2011. - №1 (7). - Т. 2. - С. 68-75.

\section{SOCIAL EMERGENCE}

\author{
O. A. Sakharova, 3rd year student, \\ e-mail: olga.sakharova.99@mail.ru \\ Kaliningrad State Technical University \\ N. V. Mednis, PhD in Philosophy \\ e-mail: natalymednis@gmail.com \\ Kaliningrad State Technical University
}

The article is devoted to the analysis of the perception of art in the digital age, changing the format of presentation and understanding. This article examines such concepts as technological progress and the causes of social emergence, the reasons leading to the fact that older people try to look many times younger than their real age, government policy and the media that have an impact on older people.

Key words: aging, elderly people, gerontology, social emergence 